成人例における人工内耳の音声コード化プログラムの調節

\author{
益田 慎 ${ }^{144}$ ・ 上田 友佳 ${ }^{1)} \cdot$ 市岡 好恵 ${ }^{1)}$ ・吉岡 麻衣 ${ }^{2)}$ \\ 岩田 和宏 ${ }^{3)} \cdot$ 平川 勝洋 ${ }^{1)} \cdot$ 夜陣 紘治 ${ }^{1}$
}

\title{
Adjustment of Cochlear Implant Speech Processing Program
}

\author{
Shin Masuda, Yuka Ueda, Yoshie Ichioka, Katsuhiro Hirakawa and Koji Yajin \\ (Hiroshima University Graduate School) \\ Mai Yoshioka \\ (Jinseikai Hosogi Hospital) \\ Kazuhiro Iwata \\ (Onomichi General Hospital)
}

\begin{abstract}
Cochlear implants require periodic adjustments of their speech processing program. The present study investigated the necessity and frequency of adjustment of the cochlear implant speech processing program in adult patients. Subjects were 19 adult patients who underwent cochlear implantation at our department and had worn the implant continuously for more than one year. A cochlear implant manufactured by Cochlear Ltd. was used in all patients: the Nucleus 22 system in 13 patients, and the Nucleus 24 system in 6 patients. Excluding adjustments made within the first month of implantation, adjustment of the speech processing program, i.e., MAPping, was performed a total of 860 times. Changes in MAP within the past three months or previously were classified as those performed to improve hearing or to alleviate adverse effects (uncomfortable noisy sensation, dizziness, earache and headache). The results were analyzed in relation to patient age at the time of surgery and hearing performance. The study showed that when MAPping was performed frequently to reduce noise, patients often experienced dizziness, earache or headache. If a patient experiences an adverse effect, while MAP might need to be adjusted, this could also worsen hearing. However, at our department, MAPping was done to deal with adverse effects without negatively affecting hearing performance.
\end{abstract}

Key words : cochlear implant, MAP, adverse effect

はじめに

人工内耳を装用するうえで，音声コード化プログラム の調節は不可欠である，当院では全例コクレア社製の Nucleusシリーズを使用しているが, コクレア社では外部 装置に記憶させる音声コード化プログラムを MAP（以
下，マップ）と称し，これを調節する作業を MAPping

(以下，マッピング）と呼んでいる.

マッピングは本来聴取機能を改善する目的で行われる が，人工内耳装用中に起きた不具合の回避を主な目的と して，マッピングをしなければならないことを少なから

1）広島大学大学院耳鼻咽喉科・頭頸部外科

2）仁生会細木病院言語療法士室

3）厚生連尾道総合病院耳鼻咽喉科

4）県立広島病院小児感覚器科 
ず経験する。

マッピングの基本的な技術とその理論的な背景は，主 には神経耳科の生理学的な根拠に基づいて理論化されて いるが，個々の症例において実際にどのように実践し結 果を得るのかという点では, 試行錯誤的な試行を繰り返 すことが多い.

例えば，音の「とげとげしさ」を軽減する目的で，補 聴器の最大出力レベルに相当する C レベル（電気的最大 刺激レベル）の值を下げても, 装用者からは期待通りの 応答が得られず, 他の複数のパラメータを変更しながら, 装用者の満足が得られるように調節を繰り返さなければ ならないこともある。

また, 補聴器とは違い, 人工内耳では痛みやめまいが 電気刺激により直接誘発されるので, マップを変更しな ければ痛みやめまいが日常生活に影響するレベルで継続 することも多い，そうなると, 聴取面で人工内耳が効果 的であっても, 感覚的には利便性が相殺されてしまう. したがって，このような有害事象が発生した場合には聴 取条件が多少不利になると予想しても，マップ変更を余 儀なくされる場合も生じる。
この報告では，これまでに当科で実施したマッピング を後ろ向きに検討し, 有害事象の発生とマッピングの目 的やその内容について検討し，実際の臨床場面における 影響について考察した。

\section{検討方法}

1）検討対象

検討対象は当科で手術を行い, 1 年以上経過を観察で きた症例のマッピングとした，当科では該当する成人症 例が 20 例あったが, このうち一例は装用側に聴神経腫瘍 を有しており，その影響をマッピングにも認めたので， 検討対象から除外した。

残る 19 例のうち 13 例は Nucleus 22 システム（以下，

表 1 聴取パフォーマンス

\begin{tabular}{cll}
\hline \hline $\mathrm{A}$ & 電話の使用に不自由しない \\
$\mathrm{B}$ & 日常会話に不自由しない \\
$\mathrm{C}$ & 読唇を併用すれば, 対話は可能 & \\
$\mathrm{D}$ & 対話の際に筆談を必要とする \\
$\mathrm{E}$ & 人工内耳聂対話の助けにならない (non User)
\end{tabular}

表 2 患者背景とセッション回数

\begin{tabular}{|c|c|c|c|c|c|c|c|}
\hline & 聴取パフォーマンス & 手術時年齢 & 機種 & $\begin{array}{l}\text { カロリリック } \\
\text { 反応の有無 }\end{array}$ & 埋込電極数 & 観察期間 & セッション総数 \\
\hline Case 1 & A & 53 & $\mathrm{~N} 22$ & 有 & 21 & 11 年 6 力月 & 50 \\
\hline Case 2 & A & 61 & N22 & 有 & 25 & 6 年 2 力月 & 30 \\
\hline Case 3 & A & 64 & $\mathrm{~N} 24$ & 有 & 21 & 2 年 3 力月 & 16 \\
\hline Case 4 & A & 21 & N24 & 有 & 27 & 1 年 10 力月 & 7 \\
\hline Case 5 & B & 52 & N22 & 有 & 22 & 6 年 9 力月 & 43 \\
\hline Case 6 & B & 20 & $\mathrm{~N} 24$ & 有 & 22 & 3 年 10力月 & 19 \\
\hline Case 7 & B & 27 & N24 & 有 & 22 & 3 年 9 力月 & 28 \\
\hline Case 8 & $\mathrm{C}$ & 51 & N22 & 有 & 20 & 9 年 2 力月 & 106 \\
\hline Case 9 & $\mathrm{C}$ & 54 & N22 & 無 & 18 & 8 年 3 力月 & 84 \\
\hline Case 10 & C & 72 & N22 & 無 & 19 & 8 年 1 カ月 & 64 \\
\hline Case 11 & $\mathrm{C}$ & 20 & $\mathrm{~N} 22$ & 無 & 14 & 8 年 0 力月 & 45 \\
\hline Case 12 & $\mathrm{C}$ & 62 & N22 & N/A & 17 & 7 年 3 カ月 & 59 \\
\hline Case 13 & $\mathrm{C}$ & 56 & N24 & N/A & 27 & 4 年 0 力月 & 21 \\
\hline Case 14 & $\mathrm{D}$ & 70 & N22 & 有 & 21 & 9 年 8 力月 & 60 \\
\hline Case 15 & $\mathrm{D}$ & 70 & $\mathrm{~N} 22$ & 有 & 22 & 8 年 5 力月 & 60 \\
\hline Case 16 & $\mathrm{D}$ & 46 & $\mathrm{~N} 24$ & 有 & 24 & 4 年 3 カ月 & 29 \\
\hline Case 17 & $\mathrm{E}$ & 74 & $\mathrm{~N} 22$ & N/A & 16 & 7 年 4 力月 & 62 \\
\hline Case 18 & $\mathrm{E}$ & 80 & $\mathrm{~N} 22$ & 有 & 22 & 4 年 9 力月 & 45 \\
\hline Case 19 & $\mathrm{E}$ & 59 & $\mathrm{~N} 24$ & 無 & 26 & 2 年 11 力月 & 32 \\
\hline
\end{tabular}


バランスをとるか，マイクのゲインコントロールにとど まった。

症例 7 と同様に, 他の症例個々について検討したが, 時系列でマッピング変更の分類, マッピングの目的をみ たときに，その特徴は見いだせなかった，たとえば，変 更 $3 \cdot 4$ のマッピングの回数が増えたら変更 5 が起きると か，不快音の制御をしていたらめまいの制御にマッピン グが必要だったとかといら特別な配列はなかった。 そこ で，以下の検討ではタイミングは考慮せず，年平均の回 数で統計学的な検討をすることとした.

2)マップ変更の年平均回数と目的別のマッピング年平 均回数

マップ変更の年平均回数を表 5 に示し, 目的別のマッ ピングの年平均回数を表 6 に示す.

マップ変更のレベル間には統計学的に有意な関係を認 めなかったが, 目的別のマッピング回数のうち, 不快音 にたいするマッピング回数は, めまいにたいするマッピ ング回数, 痛みにたいするマッピング回数との間でそれ ぞれ有意な関係を認めた $(\mathrm{p}<0.05)$.

なお，めまいにたいするマッピング回数と痛みにたい するマッピング回数の間には有意な関連はなく, とくに
聞こえの改善を目的としたマッピング回数と不快音・め まい・痛みの制御を目的にしたマッピング回数の間にも 統計学的には有意な関連を認めなかった。

患者背景と, 年間セッション回数, レベル 3 以上のマッ プ変更回数，有害事象制御のためのマッピング回数をそ れぞれ統計学的に処理した結果を表 7 に示す.

\section{考案}

1）有害事象にたいするマッピングについて

補聴器の適合とマッピングが異なる点のひとつに，人 工内耳の有害事象が蝸牛や前庭神経，あるいは髄膜・中 耳粘膜・顔面神経といった部位を直接電気刺激すること で起きる点を考慮しなければならないことがある。マッ ピングや言語聴覚療法のためのセッション時にこれを見 逃すと，適切な装用ができないばかりか結果的に人工内 耳による聴取能を低下させる場合もあり，人工内耳装用 者の QOL を低下させてしまらことにもなりかねない．

耳痛や頭痛などの痛みが人工内耳によって引き起こさ れていることを見いだし，さらに原因となっている電極 を特定することは多くの場合で容易である．試行錯誤的 に電極を減じたり，T/C レベルを変化させることで訴え

表 5 マップ变更の年平均回数

\begin{tabular}{|c|c|c|c|c|c|c|c|}
\hline & 年間セッション数 & 変更 1 & 変更 2 & 変更 3 & 変更 4 & 変更 5 & 変更 $1 \sim 5$ の合計 \\
\hline Case 1 & 4.3 & 0.1 & 0.5 & 1. 0 & 0.0 & 0.3 & 1.8 \\
\hline Case 2 & 4.8 & 0.0 & 0.5 & 1.6 & 0.0 & 0.3 & 2.4 \\
\hline Case 3 & 6.9 & 0.0 & 0.0 & 0.9 & 0.0 & 0.4 & 1. 3 \\
\hline Case 4 & 3.8 & 0.0 & 0.0 & 0.5 & 0.0 & 0.0 & 0.5 \\
\hline Case 5 & 6.4 & 0.6 & 0.1 & 0.4 & 0.0 & 0.4 & 1.6 \\
\hline Case 6 & 5.0 & 0.0 & 0.3 & 0.3 & 0.0 & 0.3 & 0.8 \\
\hline Case 7 & 7.3 & 0.3 & 0.3 & 1.0 & 0.0 & 0.3 & 1.8 \\
\hline Case 8 & 11.5 & 0.4 & 0.0 & 1.4 & 1.0 & 1. 6 & 4.5 \\
\hline Case 9 & 10.2 & 0.1 & 0.5 & 2.2 & 0.0 & 0.5 & 3.3 \\
\hline Case 10 & 7.9 & 0.0 & 1.6 & 0.4 & 0.6 & 0.1 & 2.7 \\
\hline Case 11 & 5.6 & 0.2 & 0.5 & 1.0 & 0.4 & 0.6 & 2.7 \\
\hline Case 12 & 8.1 & 0.3 & 0.5 & 3.0 & 0.5 & 0.5 & 4. 9 \\
\hline Case 13 & 5.3 & 0.0 & 0.5 & 1.8 & 0.0 & 0.3 & 2.5 \\
\hline Case 14 & 6.2 & 0.2 & 0.2 & 1.1 & 1.0 & 0.7 & 3.3 \\
\hline Case 15 & 7.1 & 0.2 & 0.1 & 1.5 & 0.9 & 1.1 & 3.9 \\
\hline Case 16 & 6.8 & 0.0 & 0.7 & 0.9 & 0.0 & 0.0 & 1.6 \\
\hline Case 17 & 8.4 & 0.4 & 0.3 & 2.0 & 0.8 & 0.4 & 3.9 \\
\hline Case 18 & 9.4 & 0.4 & 1.3 & 3. 6 & 0.4 & 1.0 & 6.7 \\
\hline Case 19 & 10.9 & 0.0 & 0.3 & 2.0 & 1.7 & 0.3 & 4.4 \\
\hline
\end{tabular}


表 6 マッピングの目的別のセッション年平均回数

\begin{tabular}{|c|c|c|c|c|c|}
\hline & \multirow{2}{*}{ きこえの改善 } & \multicolumn{3}{|c|}{ 有害事象の制御 } & \multirow{2}{*}{ 機器の不具合 } \\
\hline & & 不快音 & めまい & 痛み & \\
\hline Case 1 & 1. 0 & 0.3 & 0.0 & 0.0 & 0.3 \\
\hline Case 2 & 2.1 & 0.3 & 0.0 & 0.0 & 0.0 \\
\hline Case 3 & 0.9 & 0.0 & 0.4 & 0.0 & 0.0 \\
\hline Case 4 & 0.5 & 0.0 & 0.0 & 0.0 & 0.0 \\
\hline Case 5 & 0.9 & 1. 3 & 0.0 & 0.0 & 0.1 \\
\hline Case 6 & 0.5 & 0.0 & 0.0 & 0.0 & 0.3 \\
\hline Case 7 & 0.8 & 0.3 & 0.8 & 0.0 & 0.3 \\
\hline Case 8 & 0.9 & 1.5 & 1.4 & 2.0 & 0.4 \\
\hline Case 9 & 2.4 & 0.8 & 0.2 & 0.4 & 0.0 \\
\hline Case 10 & 2.3 & 0.6 & 0.0 & 0.0 & 0.0 \\
\hline Case 11 & 1.7 & 0.1 & 0.9 & 0.5 & 0.0 \\
\hline Case 12 & 4.1 & 1.1 & 0.0 & 0.0 & 0.0 \\
\hline Case 13 & 2.3 & 0.0 & 0.3 & 0.0 & 0.0 \\
\hline Case 14 & 2.2 & 1.1 & 0.0 & 0.3 & 0.0 \\
\hline Case 15 & 2.0 & 1.7 & 0.4 & 0.0 & 0.1 \\
\hline Case 16 & 0.9 & 0.9 & 0.0 & 0.2 & 0.0 \\
\hline Case 17 & 1.8 & 1.9 & 0.5 & 0.1 & 0.0 \\
\hline Case 18 & 4.6 & 0.4 & 1.3 & 1.0 & 0.0 \\
\hline Case 19 & 3.7 & 0.7 & 0.0 & 0.0 & 0.0 \\
\hline
\end{tabular}

表 7 Wilcoxon 検定による統計学的な検討

\begin{tabular}{lccccc}
\hline \hline & 聴取パフォーマンス & 手術時年齢 & 埋込電極数 & 使用装置 N22 vs N24 & カロリック反応の有無 \\
\hline 年間セッション回数 & $* *$ & $* *$ & $* *$ & NS & NS \\
変更 $3 \sim 5$ のマップ変更回数 & $\mathrm{NS}$ & $* *$ & $* *$ & $*$ & $\mathrm{NS}$ \\
有害事象にたいするマッピング & $* *$ & $* *$ & $* *$ & $*$ & $\mathrm{NS}$ \\
回数 & & & & & \\
$* *: \mathrm{p}<0.01, *: \mathrm{p}<0.05, \mathrm{NS}:$ 統計学的有意差なし & & &
\end{tabular}

が消失するかどうかをみれば良いことが多い。

これにたいして，めまい，特に人工内耳埋込術からあ る程度の時間をおいて遅発性に発生する浮動感について は，薬物療法やカウンセリングを推奨する報告 1)2）あ るが，マッピングによるコントロールを常に念頭におく ように勧める報告3）もある。症例 7 のように薬物療法で はコントロールができず，マップ変更がめまいの制御に 有用であった症例が実際に存在しており，当科の方針と しては薬物療法に併行して必ずマップ変更を検討するこ とにしている.

不快音の制御にいたっては，装用者の主観的な音への 感想が混在するために，取り除くべき不快音かどうかの 判断に迷うことも多い. 装用者が不快音とした音情報を むしろ強調することで，聴取成績があがることもある4).
また，元来耳鳴症を合併することが多く，耳鳴との区 別がつかないで不快音を訴える場合もあり，その場合に はマップの変更よりカウンセリングや薬物療法が有効で ある.

このため，一口に有害事象の制御のためのマッピング と称しても，必ずしも容易なことではない，例えば，め まいや痛みにたいするマッピングの必要性が事前に予測 できれば，装用者のみならずマップを作成する側にも利 点は多い.

しかし，今回の検討では不快音の制御が繰り返される と痛みが発生する，あるいは変更 $3 \sim 5$ のマップ変更が 繰り返されるとめまいが起きるなどといら時系列上の特 徵はなく, 有害事象の発生をマップやマッピングから予 測することは困難であると思われた。 
時系列上の順序を無視して，回数だけで検討したとこ ろ，不快音にたいするマッピング回数が多いと，めまい や痛みにたいするマッピングの回数が統計学的に有意に 多かった。 めまいや痛みを引き起こす刺激レベル以下の 刺激では, 不快音と感じて訴えている可能性むある31).夕 イミング上の有意な関係は見いだせなかったが，不快音 にたいするマップ変更が必要なときには，めまいや痛み の発生に注意した方が無難と思われる.

なお，術前のカロリック反応の成績と術後のめまいの 発生に関連があるともいわれている2）が，自験例に抢け る術前のカロリック反応の有無と有害事象にたいする マッピング回数の間には有意な関係はなかった.

コクレア社の人工内耳は, 日本では 2000 年に N22 か ら N24 に変更されている. 二つのシステムのマップ上の 最も大きな違いは，刺激モードの標準が Bipolor mode か ら Monopolor mode に変更になったことである．これに より，刺激電流量を大幅に減じることに成功した ${ }^{5)}$ が, これは前庭や中耳粘膜・䯙膜への期待していない電気刺 激も減らしていると推察する. 結果的に N24 の有害事象 を制御するためのマッピング回数は有意に減少してい た.

2) マッピング回数の統計学的解析について

当科の方針として, 1力月に一度から 3 力月に一度マッ プの確認をすることにしている. グループ A や B の聴取 成績の良いグループでは，個人差もあるがおおおむね半年 に一度の頻度で有意なマッピングが行われていた。グ ループ $\mathrm{C} \cdot \mathrm{D} \cdot \mathrm{E}$ では 3 カ月に一度の頻度で有意なマッピ ングが行われていた。

統計学的にも聴取パフォーマンスとマッピング回数に は有意な関連を認めており，マップを確認するタイミン グは, 聴取パフォーマンスが良ければ半年に一度, 悪け れば 3カ月に一度で良いのかもしれない。もちろん，聴 取状態に変化があったり，有害事象などの不具合が起き れば,この限りではない.

今回の検討では，手術時年齢が高く，埋め込んだ電極 数が少なければ, セッション回数, 変更 $3 \sim 5$ のマップ 変更の回数，有害事象にたいするマッピング回数のいず れも増加して抢り,きめ細かい対応が必要とされていた。

これにたいして，聴取パフォーマンスと有害事象にた いするマッピング回数の間には有意な関連を認めるもの の, 変更 $3 \sim 5$ のマップ変更の回数との間には有意な関 連を認めなかった，有害事象が増えれば，それだけ聴取
条件が不利になり,頻回のマップ変更が必要となったが, 例えば変更 $3 \sim 5$ の聴取条件が悪くなるような大きなマッ プ変更を行ったとしても聴取パフォーマンスへの影響は 少なかったといらことである.

これには，変更 $3 \sim 5$ のように聴取条件が悪くなると 予想した上でマップ変更を行った際に，例えばマキシマ を増やすなどの細かい設定変更を追加したり，聞き取り のための言語聴覚療法を追加するなど, 聴取パフォーマ ンスをなるべく維持しようとしてきた，その努力が，あ る程度有効に機能した結果, 変更 $3 \sim 5$ のマップ変更回 数が聴取パフォーマンスと有意な関係ではないという結 果を導いたと考える.

\section{まとめ}

成人人工内耳装用者に行ったマッピングを検討対象と して，マップ変更の内容とマッピングの目的について検 討した．特に，不快音，めまい，痛みの訴えを有害事象 として，その制御を目的としたマッピングに着目した。 めまいや痛みの発生をマッピングやマップ内容から事前 に予測することは困難であったが，不快音の制御を目的 にマッピングをするときには，めまいや痛みの発生に注 意する必要があると思われた，聴取条件が悪くなるよう なマップ変更の回数と聴取パフォーマンスの間には関連 はなかった。

\section{参考文献}

1）清水謙祐, 小宗静男, 東野哲也, 他 : 人工内耳症例に抒け る術後めまいの検討. Otol Jpn $9: 588 ＼mathrm{~ 593 ， 1999 . ~}$

2) Kubo T, Yamamoto K, Iwaki $T$, et al. : Different forms of dizziness occurring after cochlear implant. Eur Arch Otorhinolaryngol $258: 9 \sim 12,2001$.

3) Fina M, Skinner M, Goebel JA, et al. : Vestibular dysfunction after cochlear implantation. Otol Neurotol $24: 234 \sim 242$, 2003.

4) Skinner MW : Optimizing cochlear implant speech performance. Ann Otol Rhino Laryngol Suppl $112: 4 \sim$ 13, 2003.

5) Zwolan TA, Kiley PR, Ashbaugh C, et al. : Patient performance with the cochlear corporation " $20+2$ " implant bipolar versus monopolar activation. Am J Otol $17: 717 \sim 723,1996$.

別刷請求先：益田 慎 ₹734-8530 広島市南区宇品神田1-5-54 県立広島病院小児感覚器科 